УДК 811.111 '371’42:82-3«20»

DOI https://doi.org/10.26661/2414-1135-2021-83-39

\title{
ОСНОВНІ РИСИ ЛЕКСИКО-СЕМАНТИЧНОГО ПРОСТОРУ БРИТАНСЬКИХ ХУДОЖНІХ ПРОЗОВИХ ТЕКСТІВ НА ВІЙСЬКОВУ ТЕМАТИКУ ПОЧАТКУ ХХІ СТОЛІТТЯ
}

\author{
Шайнер I. I. \\ кандидат філологічних наук, \\ доиент кафедри іноземних мов для гуманітарних факультетів \\ Львівський національний університет імені Івана Франка \\ вул. Університетська, 1, Львів, Україна \\ orcid.org/0000-0001-6316-0026 \\ irene1005@i.ua
}

\begin{abstract}
Ключові слова: художній текст, лексико-семантичний простір, лексико-семантичні / лексико-тематичні / лексикоасочіативні угруповання, семантична домінанта, прагмастилістика.
\end{abstract}

Статтю присвячено узагальненню основних рис лексико-семантичного простору британських художніх прозових текстів на військову тематику (ТВТ) початку XXI ст. Поставлені у праці завдання вирішено з урахуванням багатоаспектності феномена лексико-семантичного простору художнього тексту. Увагу зосереджено на особливостях дослідження лексикосемантичного простору художнього тексту з позицій прагмастилістичного підходу. Виділено головні особливості лексико-семантичного простору сучасних британських художніх прозових ТВТ, наголошено на ролі семантичної домінанти у його композиційно-архітектонічній структурі, зазначено напрями функціонування лексичних мікросистем у художніх творах із різним ступенем експлікації військової тематики.

Лексико-семантичнийпростірсучасних британських ТВТ виформовується завдяки тісній кореляції лексико-семантичних, лексико-тематичних та лексико-асоціативних угруповань. Особливістю британських ТВТ початку XXI століття $є$ те, що тема війни простежується не лише на першому плані, але й на рівні мікровкраплень. Лексичні одиниці у XТ із макро- та мезовкрапленнями військової тематики підібрані та організовані таким чином, щоб якомога чіткіше передати страшні реалії воєнного світу, тоді як ХT із мікровкрапленнями військової тематики демонструють вплив війни на внутрішній стан та свідомість людини ще тривалий час після іiі завершення.

Загалом аналіз лексико-семантичного простору у трьох напрямах його розгортання дав змогу виділити такі особливості його функціонування: лейтмотив авторського задуму - особливості військових дій та їх вплив на людину та суспільство (семантичний рівень); основна тема - людина у воєнний або повоєнний період (тематичний рівень); забезпечення естетичного задоволення від твору за допомогою експресивностилістичного забарвлення та художнього переосмислення найбільш значущих одиниць (асоціативний рівень). Вибір автором військової тематики зумовлений інтенцією передати на яскравих прикладах минулого згубність війни, закликати людство запобігти таким катастрофам у майбутньому. 


\title{
KEY FEATURES OF THE LEXICAL-SEMANTIC SPACE OF BRITISH MILITARY FICTION PROSE TEXTS OF THE BEGINNING OF THE 21st CENTURY
}

\author{
Shainer I. I. \\ Candidate of Philological Sciences, \\ Associate Professor at the Department of Foreign Languages for the Humanities \\ Ivan Franko National University of Lviv \\ Universytetska str., 1, Lviv, Ukraine \\ orcid.org/0000-0001-6316-0026 \\ irene1005@i.ua
}

Key words: literary text, lexicalsemantic space, lexical-semantic / lexical-thematic / lexicalassociative groupings, semantic dominant, pragmatic stylistics.
The article focuses on the generalization of the main characteristics of the lexical-semantic space of the British prose military fiction texts (MFTs) of the beginning of the 21 st century. Considerable attention is paid to the main ways of study of the lexical-semantic space of a literary text on the basis of pragmatic-stylistic approach. As a result, the dominant features of the lexicalsemantic space of the contemporary MFTs were outlined, the role of a semantic dominant in its compositional-architectonic structure was emphasized, the vectors of the functioning of the lexical microsystems in the texts with different degrees of the military theme explication were pointed out.

Lexical-semantic space of the contemporary British MFTs is composed due to the close correlation of lexical-semantic, lexical-thematic and lexicalassociative groups. A peculiar feature of the British MFTs of the beginning of the 21 st century is the fact that the war theme is observed not only in the foreground, but at the level of micro-inclusions as well. Lexical units in the texts with macro- and meso-inclusions of military themes are organized in such a way that they clearly depict the terrifying reality of the war environment, while the texts with micro-inclusions of military themes demonstrate the power of war on the inner state and consciousness of a person even long after its ending. Thus, analysis of the lexical-semantic space in the 3 directions of its expansion enabled highlighting such main features of its functioning: a leitmotif of the author's intention - peculiarities of military actions and their influence on a person and society (semantic level); the main theme - a person in a war or postwar time (thematic level); providing the aesthetic satisfaction from the literary text by means of expressive-stylistic colorings and literary interpretations of the most signifying units (associative level). The author's choice of military themes is determined by the intention to represent fatality of war with the help of bright examples of the past, to appeal to the mankind to prevent similar disasters in the future.
Постановка проблеми. У зв'язку з нестабільністю у сучасному світі дедалі більше авторів у своїх творах зачіпають тему війни та, відповідно, зростає інтерес науковців до дослідження особливостей експлікації військової тематики у художніх текстах (далі - ХТ) різних жанрів [8; 12; 20; 23; 26]. Проте вважаємо, що це питання є малодослідженим у науковій літературі. Зокрема, детальнішого вивчення потребує лексико-семантичний простір сучасних художніх прозових текстів на військову тематику (далі - ТВТ), особливості його наповнення, причини, що зумовили використання певних лексичних засобів, а також їх ефект на читача (прагмастилістична спрямованість).
У цій статті в результаті проведеного дослідження узагальнено основні риси лексико-семантичного простору британських художніх прозових TBT початку XXI ст. У процесі дослідження було застосовано методику системного аналізу лексико-семантичного простору художніх ТВТ початку XXI ст., що грунтується на поєднанні загальнонаукових (спостереження, опис, індукція, дедукція, систематизація) та емпірико-теоретичних (аналіз, синтез) методів. Зазначимо, що методологічною основою вивчення лексико-семантичного простору сучасних художніх ТВТ було вибрано антропологічну та прагмастилістичну парадигми, адже в центрі будь-якого твору, беззаперечно, 
є людина з їі особливостями переживання різного роду життєвих ситуацій.

Отже, надзвичайно актуальним залишається питання вивчення лексико-семантичних та прагмастилістичних особливостей ХТ сучасності як втілення неповторного авторського задуму та світогляду. Мета статті - узагальнити та виокремити основні риси, що характеризують лексико-семантичний простір британських художніх прозових текстів на військову тематику початку XXI ст.

Виклад основного матеріалу дослідження. Лексико-семантичний простір $X T$ - це складна система лексичних одиниць, що об'єднуються в мікросистеми (поля, групи, підгрупи тощо) на основі спільної тематики та концептуального значення, репрезентують певну понятійну сферу $[2$, с. $4 ; 5$, с. $9 ; 10$, с. 115$]$, згуртовуються навколо центральних семантичних домінант ХT. Вибір автором певних лексичних одиниць у творі здатний впливати певним чином на інтерпретацію, емоційний стан та загальне сприйняття тексту читачем. Лексико-семантичний простір сучасних британських художніх прозових ТВТ характеризується низкою особливостей. Розглянемо детальніше кожну 3 них.

1. Триєдність напряму розгортання. Більшість дослідників зазначають, що внаслідок взаємодії лексичної та семантичної підсистем виформовуються семантичні, тематичні й асоціативні особливості розвитку значення лексичних одиниць $[7 ; 9 ; 15 ; 24 ; 30]$. Відповідно, вважаємо доцільним виокремлення трьох осей розгортання лексико-семантичного простору сучасних художніх ТВТ: семантичної (граматика тексту), тематичної (лінгвістика тексту) й асоціативної (стилістика тексту). Вкупі вони транслюють загальну ідею художнього твору: безглуздість війни та іiі руйнівні наслідки як для окремої людини, так i суспільства загалом.

2. Об'єднання лексичних одиниць у лексико-семантичні, лексико-тематичні та лексико-асоціативні мікросистеми (поля і групи). Найбільшим за об'ємом угрупованням, якому властива спільна смислова основа, вважають лексико-семантичне поле (ЛСП) [21, с. 144; 25, с. 10; 27, с. 76]. До лексико-тематичних угруповань зараховують класи слів, які «об'єднуються однією і тією ж типовою ситуацією чи темою» [6, с. 110]. Варто зазначити, що лексико-тематичні мікросистеми відображають особливості внутрішньої організації тексту: від мікро- до макроструктури [13, с. 280], від метатеми до підтем [15, с. 54]. Визначальною рисою ЛТГ є позамовна зумовленість зв'язків між ії елементами [3, с. 31]. Значну увагу дослідників привертає виняткова роль асоціативного збагачення лексичних одиниць, адже саме вони надають значенням певних слів чи лексичних структур яскравих смислових частинок $[1$, с. $60 ; 17$, с. $90 ; 18$, с. 37]. Отже, вважаємо доцільним виокремлення ще однієї важливої мікросистеми - лексико-асоиіативних угруповань. Нагадаємо, що основною відмінністю поля від групи $\epsilon$ його ядерно-периферійна будова $[11$, с. 282]. Зазвичай поле складається 3 одиниць різних частин мови і є об'ємнішим угрупованням, йому властиві ієрархічні зв'язки між конституентами мікрополів, груп і підгруп. Щодо групи, то іï елементам притаманні зв'язки субституції та комутації [9, с. 275]. Як відомо, поля в лексико-семантичному просторі ХТ не існують ізольовано: вони взаємодіють, нерідко пересікаючись та накладаючись одне на інше $[18$, с. $69 ; 25$, с. 12]. Відповідно, одна одиниця може входити відразу до складу кількох полів.

3. Виокремлення лексико-семантичних угруповань як способу експлікації домінантних семантичних (ідейних) понять у творі: війна, іiі вплив на емоції та внутрішній стан, мислення i поведінку людини. Отже, військова тематика (ВТ) актуалізується в тексті лексичними одиницями, що позначають: військові реалї, військові дї, емоияійний стан та емоияійні реакиії, поведінку та мисленнєві процеси. Їх кількість у ТВТ становить від $23 \%$ до 32\% та 38\%, відповідно, можемо говорити про тексти з макро-, мезо- та мікровкрапленнями військової тематики. Лексичні структури у ХT із макро- та мезовкрапленнями ВТ покликані передавати реалії воєнного та повоєнного середовища, загальну атмосферу, внутрішній стан людини та фізичні прояви їі дій у процесі війни. Проте важко применшити роль цих лексичних одиниць у твоpax iз мікровкрапленнями ВТ, адже деталі воєнного середовища виконують функцію наближення читача до світу художньої дійсності, створюють особливий емоційний фон для розгортання інших подій. Наприклад: "She shook her head, unconvinced. 'It was more than mere anger. It was as though the war itself had changed him, made an utter stranger of him. He seemed to hate himself, and everyone around him. Oh, when I think of all the boys like him, and all the frightful things we asked them to do in the name of making peace!',' [29]. Згадки про війну неначе відлунюють у наративній лінії персонажів, передаючи іiі руйнівні наслідки ще довго після iї завершення.

4. Лексико-тематичні угруповання, що передають домінантні теми ХT, такі як: військових реалій та явищ, а також теми людського тіла, медицини та здоров'я, навколичнього природного середовища. Усі ці мікросистеми вкупі гармонійно доповнюють тему згубності війни, демонструючи антропологічну спрямованість сучасних ТВТ (фізичні та психологічні травми, внутрішній стан i почуття персонажів, зумовлені перебігом воєн- 
них дій). Розглянемо уривок, що передає фізичні травми молодої людини, спричинені війною: "A tall mirror was positioned in the corner of the room and I stood in front of it, examining my body with a critical eye. My chest, which had been well toned and muscular in late adolescence, had lost most of its definition in recent times; it was pale now. Scars stood out, red and livid across my legs; there was a dark bruise that refused to disappear stretched across my abdomen. I felt desperately unattractive. Once, I knew, I had not been so ugly" [14]. Лексичні одиниці, що виражають тему військових реалій та явищ, становлять $39 \%, 33 \%$ і $27 \%$ у творах із макро-, мезо- та мікровкрапленнями ВТ відповідно. Особливістю функціонування лексико-тематичних угруповань у творах із мікровкрапленнями ВТ $є$ створення ефекту відлуння війни впродовж цілого твору, що сприяє реалістичній передачі однієї з глобальних тем, порушених автором.

5. Лексико-асоціативне збагачення лексико-семантичних та лексико-тематичних одиниць у напрямах: увиразнення ознак боротьби, евфемізації військових реалій, експресивно-стилістичного підсилення значення уніформи у воєнний період, відтворення особливостей внутрішнього стану та тілесних травм, спричинених війною. Зазначимо, що у творах із мікровкрапленнями ВТ простежуємо лише елементи експресивно-стилістичного увиразнення військових подій, в поєднанні 3 передачею особливостей внутрішнього стану людини та їі тіла, понівеченого війною. Лексико-асоціативне угруповання «Війна» у творах із макро-, мезо- та мікровкрапленнями ВТ становить $33 \%, 28 \%$ та 22\% відповідно. Наступний уривок демонструє експресивно-стилістичне підсилення значення уніформи у воєнний період: “The German laughed again, took another strawberry and made his way back through the crowd, his black uniform oddly funereal among the bright patchwork of the market. Later my mother tried to explain. All uniforms were dangerous, she told me, but the black ones above all" [19].

6. Семантичні домінанти, тобто превалювання в художньому тексті певних лексичних одиниць, об'єднаних спільною темою, семантичним або асоціативним значенням, а також їх текстотвірна роль у забезпеченні цілісності лексико-семантичного простору ХT [21; 22; 27]. Тому в нашому дослідженні під семантичною домінантою ми розуміємо наскрізну присутність проблеми, смисловий згусток і лейтмотив ХТ. Це дає змогу виокремити такі ключові семантичні домінанти: «Людина», «Воєнний час», «Природа», що функціонують у кількох напрямах: оповідної інтродукції, увиразнення та динамічності оповіді, попередження сюжетного загострення, проміжної ланки текстової оповіді, створення певної тональ- ності, емоційного фону у творі. Незважаючи на те, що домінанта «Воєнний час» у XТ із мікровкрапленнями ВТ виражена більш імпліцитно, вона виконує не менш важливу текстотвірну роль: згадки про війну наголошують тривалість і11 деструктивних наслідків для людини.

7. Прагматична спрямованість на читача. Оскільки лексико-стилістичні засоби вибираються автором для реалізації певних прагматичних цілей, це дає підставу говорити про існування прагмастилістичної парадигми. Прагмастилістика зосереджується на інтерпретації смислу ХТ й окремих лексико-стилістичних засобів та структур читачем $[16$, с. $6 ; 28$, с. 364$]$. Отже, прагмастилістика (будучи антропоцентричною у своїй основі) фокусується на: впливі інтенцій та стратегій мовця/автора на вибрані ним засоби мови; ролі авторських інтенцій і тактик у формуванні функціональних стилів; взаємодії намірів, стратегій і тактик мовця та стилю його мовлення; авторських інтенціях та стратегіях, які формують індивідуально-художній стиль письменника; загальному контексті або позалінгвальній ситуації [4, с. 9-10; 28 , с. $373 ; 16$, с. $10-16]$. Ще одним завданням прагмастилістики є дослідження та пояснення того, як взаємодіють контекстуальні припущення 3 лінгвально закодованим смислом i, відповідно, як виникають та розвиваються певні інтерпретації лексичних структур [16, с. 6-7]. Усі лексичні структури у досліджуваних ХТ вибрані авторами з особливою метою - створення певної атмосфери та здійснення задуманого впливу на читача. На авторські інтенції неминуче впливає соціальний, позалінгвальний контекст. Це чітко виражено у творах з елементами ВТ, адже їі мікровкраплення часто проникають і у твори інших жанрів.

Висновки. Отже, лексико-семантичний простір - це складна система лексичних одиниць та структур, об'єднаних навколо спільної семантичної ідеї, тематики та збагачених стилістично-асоціативним забарвленням. 3 огляду на це можна виокремити лексико-семантичні, лексико-тематичні та лексико-асоціативні мікросистеми, а також певні смислові вузли - семантичні домінанти. Комплексне дослідження лексико-семантичного простору у трьох напрямах його розгортання дало змогу виявити та проаналізувати системне використання певних лексичних одиниць, що передають провідні авторські ідеї та концепти у творі, визначити їх кількісну репрезентацію та особливості функціонування у ХT. Прагмастилістичний підхід (у поєднанні з іншими методиками) вважаємо перспективним у подальших дослідженнях лексико-семантичного наповнення сучасних художніх текстів різної тематики та різних жанрів, оскільки він передбачає глибше занурення в екстралінгвальний контекст. 


\section{ЛІТЕРАТУРА}

1. Алефиренко Н.Ф. Спорные проблемы семантики : монография. Москва : Гнозис, 2005. $326 \mathrm{c}$.

2. Антипина Е.С. Лексико-семантическое пространство дневника писателя : автореф. дис. ... канд. филол. наук : 10.02.01. Иваново, 2015. $24 \mathrm{c}$.

3. Банкевич В.В. К вопросу о соотношении ЛСГ и тематических групп. Семантика слова и предложения. 1985. С. 30-35.

4. Безугла Л.Р. До питання розмежування прагматики, стилістики та прагмастилістики. Bicник Харківського національного університету ім. В.Н. Каразіна. 2014. Вип. 77. № 1102. C. 6-11.

5. Бехта I.A., Шайнер I.I. Лексичні структури британських художніх прозових текстів на військову тематику. Науковий вісник Херсонського державного університету. Серія «Германістика та міжкультурна комунікація». 2019. Вип. 2. С. 7-11.

6. Васильев Л.М. Теория семантических полей. Bопросы языкознания. 1971. № 5. С. 105-113.

7. Карпенко Ю.О. Вступ до мовознавства: підручник. Київ : Вид. центр “Академія”, 2006. $336 \mathrm{c.}$

8. Качак Т. Тема війни і миру в сучасній українській прозі для дітей та юнацтва. Українська література в загальноосвітній школі. 2015. № 3. С. 22-24.

9. Левицкий В.В. Семасиология: изд. 2. Винница : Нова Кныга, 2012. 672 с.

10. Попова Н.Б. Концептуальное представление семантического пространства многозначного слова. Вестник Челябинского государственного университета. 2011. Вып. 52. С. 114-117.

11. Селіванова О.О. Сучасна лінгвістика: напрями та проблеми : підручник. Полтава : Довкілля-К, 2008. 712 c.

12. Barlow A. The Great War in British Literature: Cambridge Contexts in Literature. Cambridge, 2000. $130 \mathrm{p}$.

13. Berrio A.G. A Theory of the Literary Text / transl. by K.A. Horn. Berlin, 1992. 544 p.

14. Boyne J. The Absolutist : ebook. 2011. 497 p.

15. Bremond C. Concept and Theme. The Return of Thematic Criticism / ed. by W. Sollors. Cambridge: Harvard University Press, 1993. P. 46-59.

16. Chapman S., Clark B. Pragmatic Literary Stylistics. London, 2014. 229 p.

17. Gee J.P. An Introduction to Discourse Analysis. New York, 2010. 218 p.

18. Geeraerts D. Theories of Lexical Semantics. Oxford, 2009. $317 \mathrm{p}$.

19. Harris J. Five Quarters of the Orange : ebook. $2001.522 \mathrm{p}$.
20. Hart J. The Poetics of Otherness: War, Trauma and Literature. New York, 2015. 263 p.

21. Hope J., Wright L. Stylistics: A Practical Coursebook. New York: Routledge, 2005. 183 p.

22. Salkie R. Text and Discourse Analysis. London : Routledge, 2001. $115 \mathrm{p}$.

23. Sarma G. The War Novel: Hemingway and After: thesis for the degree of $\mathrm{PhD}$. Shillong, 2001. $223 \mathrm{p}$.

24. Shead S.L. Radical Frame Semantics and Biblical Hibrew: Exploring Lexical Semantics. Boston, 2011. $378 \mathrm{p}$.

25. Simon-Vandenbergen A.-M., Aijmer K. The Semantic Field of Modal Certainty: A Corpus-Based Study of English Adverbs. Berlin, 2008. 405 p.

26. Smith A.K. The Second Battlefield: Women, Modernism and the First World War. Manchester, 2000. $214 \mathrm{p}$.

27. Toolan M. Language in Literature: An Introduction to Stylistics. New York, 2013. 250 p.

28. Warner Ch. Literary Pragmatics and Stylistics. The Routledge Handbook of Stylistics / ed. by M. Burke. London, New York : Routledge, 2014. P. 362-377.

29. Waters S. The Little Stranger: ebook. 2009.914 p.

30. Wise H. The Vocabulary of Modern French: Origins, Structure and Function. London, 2003. $270 \mathrm{p}$.

\section{REFERENCES}

1. Alefirenko, N. (2005). Spornye probliemy semantiki [Controversial problems of semantics]: monograph. Moscow: Gnozis.

2. Antipina, Ye. (2015). Leksiko-semanticheskoye prostranstvo dnievnika pisatielia [Lexicalsemantic space of a writer's diary]. Abstract of a $\mathrm{PhD}$ thesis, Ivanovo).

3. Bankevych, V. (1985). K voprosu o sootnoshenii LSG i tiematicheskikh grupp [To the problem of LSG and thematic groups correlation]. Semantika slova i priedlozheniya, 30-35.

4. Bezuhla, L. (2014). Do pytannia rozmezhuvannia prahmatyky, stylistyky ta prahmastylistyky [To the problem of differentiation of pragmatics, stylistics and pragmatic stylistics]. Visnyk Kharkivskoho natsionalnoho universytetu im. V.N. Karazina, is. 77, № 1102, 6-11.

5. Bekhta, I., Shainer, I. (2019). Leksychni struktury brytanskyh khudozhnikh prozovykh tekstiv na viiskovu tematyku [Lexical combinations of British military fiction prose texts]. Naukovyi visnyk Khersonskoho derzhavnoho universytetu. Seriya "Hermanistyka ta mizhkulturna komunikatsiya”, 2, 7-11.

6. Vasilyev, L. (1971). Tieoriya semanticheskikh poliei [Theory of semantic fields]. Voprosy yazykoznaniya, 5, 105-113. 
7. Karpenko, Yu. (2006). Vstup do movoznavstva [Introduction to linguistics]: manual. Kyiv : Vyd. tsentr "Akademiya".

8. Kachak, T. (2015). Tema viiny i myru v suchasnii ukrainskii prozi dlia ditei ta yunatstva [The theme of war and peace in contemporary Ukrainian prose for kids and youths]. Ukrainska literature $v$ zahalnoosvitnii shkoli, 3, 22-24.

9. Lievitskii, V. (2012). Semasiologiya [Semasiology]: pub. 2. Vinnytsia: Nova Knyha.

10. Popova, N. (2011). Kontseptualnoye priedstavlieniye semanticheskoho prostranstva mnogoznachnogo slova [Conceptual representation of the semantic space of a polysemantic word]. Viesnik Chieliabinskoho gosudarstviennoho univiersitieta, 52, 114-117.

11. Selivanova, O. (2008). Suchasna linhvistyka: napriamy ta problemy [Modern linguistics: directions and problems]: manual. Poltava: Dovkillia-K.

12. Barlow, A. (2000). The Great War in British Literature: Cambridge Contexts in Literature. Cambridge.

13. Berrio, A.G. (1992). A Theory of the Literary Text / transl. by K.A. Horn. Berlin.

14. Boyne, J. (2011). The Absolutist: ebook.

15. Bremond, C. (1993). Concept and Theme. The Return of Thematic Criticism / ed. by W. Sollors. Cambridge: Harvard University Press, 46-59.

16. Chapman, S., Clark, B. (2014). Pragmatic Literary Stylistics. London.

17. Gee, J.P. (2010). An Introduction to Discourse Analysis. New York.
18. Geeraerts, D. (2009). Theories of Lexical Semantics. Oxford.

19. Harris, J. (2001). Five Quarters of the Orange: ebook.

20. Hart, J. (2015). The Poetics of Otherness: War, Trauma and Literature. New York.

21. Hope, J., Wright, L. (2005). Stylistics: A Practical Coursebook. New York : Routledge.

22. Salkie, R. (2001). Text and Discourse Analysis. London : Routledge.

23. Sarma, G. (2001). The War Novel: Hemingway and After: thesis for the degree of $\mathrm{PhD}$. Shillong.

24. Shead, S.L. (2011). Radical Frame Semantics and Biblical Hibrew: Exploring Lexical Semantics. Boston.

25. Simon-Vandenbergen, A.-M., Aijmer, K. (2008). The Semantic Field of Modal Certainty: A Corpus-Based Study of English Adverbs. Berlin.

26. Smith, A.K. (2000). The Second Battlefield: Women, Modernism and the First World War. Manchester.

27. Toolan, M. (2013). Language in Literature: An Introduction to Stylistics. New York.

28. Warner, Ch. (2014). Literary Pragmatics and Stylistics. The Routledge Handbook of Stylistics / ed. by M. Burke. London; New York : Routledge, 362-377.

29. Waters, S. (2009). The Little Stranger: ebook.

30. Wise, H. (2003). The Vocabulary of Modern French: Origins, Structure and Function. London. 